\title{
Book Review: Education for Retirement Programs
}

\author{
Noêmia de Morais Santos ${ }^{1}$ \\ Departamento de Psicologia Social e do Trabalho, Universidade de Brasília, \\ Brasilia, DF, Brazil
}

\begin{abstract}
Book Review: Murta, S. G., Leandro-França, C., \& Seidl, J. (2014). Programas de Educação para a Aposentadoria: Como planejar, implementar e avaliar. Novo Hamburgo, RS: Sinopsys.
\end{abstract}

\section{Resenha do livro: Programas de Educação para Aposentadoria}

\section{Reseña del libro: Programas de Educación para el Retiro}

The book presents valuable contributions for psychologists, managers, researchers and all those who are interested in active aging, successful retirement and, above all, the Education for Retirement Programs (ERPs). It is organized into five parts: Foundations; Planning of Education for Retirement Programs; Themes and Strategies for Education for Retirement Programs; and Research. It also provides an annex with interesting supplementary materials for the preparation of ERPs.

The presentation, written by the organizers Sheila Giardini Murta, Cristineide LeandroFrança and Juliana Seidl, highlights that the process of commencing retirement is marked by the duality of feelings and expresses the hope of promoting retirement with well-being.

The work has the participation of 19 Brazilian specialists in the area of retirement from various organizations: University of Brasilia (UNB), Federal University of Santa Catarina (UFSC), Rural Federal University of Rio de Janeiro (UFRRJ), Salgado de Oliveira University (UNIVERSE), Fiocruz Brasilia and the Central Bank of Brazil.

Mailing address: Universidade de Brasília, ICC Sul, Instituto de Psicologia/PSTO, Caixa Postal: 04500, Brasília, DF, Brazil 70910-900. Phone: (61)3107-6827/6830. E-mail: santos.morais. noemia@gmail.com
The first chapter, Prevention and Promotion OF Mental Health, Public Policies on Active Ageing and Education for Retirement (Leandro-França, 2014b), presents the concepts and models of prevention and promotion of mental health and, considering the increase in aging, highlights national and international policies that support ERPs and aging. With reference to the Older Adult Statute, determinant factors of active aging are described, such as: individual, economic, social, behavioral, health and social services and physical environment factors. Furthermore, the need is considered for ERPs for workers from all areas, starting at least one year from the probable date of retirement.

The second chapter, Theoretical Models that Support the Education for Retirement Programs (Günther \& Borges, 2014), draws attention to three major theories that support the ERPs: The Life Span Perspective, the Resiliency Model and the Transtheoretical Model of Change.

The first theory emphasizes that development is a process marked by losses and gains, by continuity and change that requires adaptation to

Manuscrito elaborado a partir da dissertação de mestrado, no Programa de Pós-Graduação em Psicologia Social, do Trabalho e das Organizações (PG-PSTO), Phone (61) 3107-6830 www.psto. com.br 
new stages of life, for example, retirement. The second theory, through the concept of resilience, clarifies the ability to face the adversities of life successfully. The third theory aims to understand how people progress through behavioral change in relation to health, financial planning, strengthening of the family and social network and post-career life projects.

This chapter also covers group intervention strategies to achieve changes in behavior, according to the internal stage of preparation for retirement in which participants are: pre-contemplation to contemplation, contemplation for preparation, preparation for action and action for maintenance.

The third chapter, Retirement: Crisis or Freedom (Leandro-França, 2014a) reports the duality of feelings arising from retirement. It portrays the characteristics of retirement marked by suffering or by pleasure. In this chapter, the importance is emphasized of financial preparation, planning for the future, the practice of physical activity, leisure and healthy eating, aiming for a successful retirement.

The fourth chapter, Management of Psychoeducational Groups (Murta, Borges, \& Costa, 2014) deals with the importance of psychoeducational practices through groups for individuals to reflect on the moment of retirement and post-career, as well as on plans for the future: free time, projects, activities, another profession. These groups go beyond providing information on the subject and valorize the experiences, feelings and expectations for retirement.

It is hoped that these groups encourage the development of capabilities and meaningful interactions, so that, through the sense of belonging and social support received, the participants can increase their resilience and empowerment. The format, the planning, the therapeutic factors and the skills necessary for the facilitator are also discussed.

The fifth chapter, Formats of Education for Retirement Programs (Seidl, LeandroFrança, \& Murta, 2014), is focused on the characteristics of the different types of intervention: continuing, short and intensive, which will be defined according to the need and the resources available in the organization.

Based on the concept that aging is a stage of human development, it is suggested that the ERPs are incorporated early on in the career for their best applicability throughout the working life. However, it is noted that currently only public services and large companies have invested in such programs.

The sixth chapter, Planning of Education Programs for Retirement (Zanelli \& Antloga, 2014), covers the advantages of preparing for retirement and once again draws attention to early preparation. It suggests the means for the development of programs, namely: comprehension of the context, preparation of the project, training of the supervisors, adequation of the program, implementation and evaluation.

The seventh chapter, Identity, Values and New Professional Perspectives (Seidl \& Conceição, 2014), deals with the risk of having an exaggerated single social role, in the case of the worker, which may cause suffering in the retirement process due to a possible identity crisis. It also addresses the importance of relating the values of the participants to their behaviors. It reports that, in response to increased life expectancy, many people have chosen to continue working after retirement, with the need therefore arising to think of new professional perspectives.

The eighth chapter, Cognitive Functions, Aging and Retirement: Memory and Intervention Techniques (Chariglione \& Janczura, 2014), focuses on the decline of the memory in the normal aging process, as well as intervention techniques to minimize this, such as: memorization, relaxation and attention.

The ninth chapter, Healthy Thinking in Retirement (Kunzler, 2014), deals with the contributions of the decision-making and quality of life technique, a form of cognitive therapy, for the promotion of quality of life in retirement. In this, individuals are instructed to think that there is more than one point of view for a given event and the way they see it is a personal choice.

It is reported that, since 1980, the benefit of cognitive approaches in group care has been 
proven. Therapeutic care, in groups, reduces costs and increases the number of individuals that benefit. Therefore, its use in ERPs, by a qualified professional, is indicated.

The tenth chapter, Family and Marital Relationships in Retirement (França \& Sandoval, 2014), highlights family relationships as the main dimension analyzed in making decision regarding retirement, followed by the factors that affect health conditions. Therefore, all ERPs should include this topic to help older adults reflect and discuss such an important theme with their families, since the strengthening of this network can provide important support in the retirement.

Broadening the debate, the eleventh chapter, Social Network and Retirement (Costa \& Malaquias, J. V. 2014), draws attention to the importance of the social relationships as a whole: family, friends and community. It considers the tendency for the social network to diminish in old age, the reduction of the opportunities to renew the social network and the difficulty of maintaining already active bonds due to the tendency to focus more on family relationships. In this context, social networks create a space for a dynamic exchange, especially for those living in similar situations, in which solidarity between people will enable them to share problems and find solutions.

The twelfth chapter, Financial Autonomy in Retirement (Pimenta, 2014) is dedicated to financial planning, which should be started early in the working life. It is desirable that the employee invests part of his/her resources throughout their professional career so that they can be financially independent in retirement.

Attention is drawn to financial education within the family context aimed at the family learning together to deal with the decisions regarding financial resources, life projects and the commitment of the income to consumption and investment. Investment options are also suggested, in order to enjoy a peaceful retirement.

The thirteenth chapter, (Re)discovering Leisure in Retirement (Seidl, 2014), discusses the ways to enjoy this stage of life, dispelling the negatives aspects and stereotypes of old age.
Consistent with the previous chapters, it emphasizes that leisure activities should be part of daily life, throughout life, and that people should not wait until retirement to devote themselves to pleasurable activities.

The fourteenth chapter, Spirituality, Health Promotion and Retirement (Neubern, 2014), portrays how spirituality can help in the health promotion process in the context of retirement. Sometimes, spirituality is a source of flexibility, helping the person to redefine and comprehend the vicissitudes of life and, through it, the retiree can construct understanding of striking issues of the life course, such as: change of social roles, development and adaptation, disease and death, among others.

The fifteenth chapter, Life projects, Values and Commitment to Action in Retirement (França, Barbosa, \& Murta, 2014), explains the importance of life projects when retiring. The diversity of activities prior to this phase is a facilitating factor for the process.

It is proposed that the ERPs should finish with this issue, considering its importance for a successful transition to retirement. Attention is drawn to the important items in this topic: life project: its dimensions and related variables, well-being and happiness, personal values and commitment to personal projects and techniques for finishing ERPs, involving reflection and discussion about future projects.

The sixteenth and final chapter, Research in Evaluation of Education for Retirement Programs (Murta, Leandro-França, \& Barbosa, 2014), describes the criteria of the research script, prior to the implementation of an ERP: needs assessment, program development, efficacy assessment, evaluation of effectiveness and studies of diffusion of successful ERPs.

The paucity of studies in Brazil related to ERP evaluation is reaffirmed and the importance of such studies to ensure the effectiveness of programs is highlighted, with investment in robust studies in this area suggested.

Finally, it is important to note that to retire often does not mean to stop working. A person can retire and develop the same activity in another organization, can engage in another pro- 
fessional facet, or can develop, throughout life, a second activity that becomes an occupation after retirement. In this context, ERPs can be useful for those who aim to cease all work activities, as well as those who aim to continue working.

In order to support the retirement phase, it is suggested, based on the life course perspective, that young workers are also included in the ERP, especially those at the beginning of the career, aiming for management of the career with a preventive approach and for education throughout the life (Murta et al., 2014).

It is hoped that the dissemination of ERPs becomes a national reality, considering that today the majority of the programs are limited to the sphere of public companies and a few large companies. Therefore, a cultural change regarding aging is necessary in the organizational environment, aiming to increase ERPs as suggested by this work.

The book covers the main aspects that must be present in ERPs. Furthermore, it emphasizes the theoretical aspects that an ERP needs to be base on. Finally, it stresses the importance of investing in systematic and continuous evaluation of these programs and draws attention to the paucity of Brazilian studies for the evaluation of the various stages of ERPs: adoption, implementation, dissemination and sustainability.

To read this work is recommended in view of its contribution to the teaching, supervision, professional practice, research and training of professionals who intend to work with ERPs and aging.

\section{References}

Chariglione, I. P. F., \& Janczura, G. A (2014). Funções cognitivas, envelhecimento e aposentadoria. In S. G. Murta, C. Leandro-França, \& J. Seidl (Eds.), Programas de Educação para Aposentadoria (pp. 68-83). Novo Hamburgo, RS: Sinopsys.

Costa, L. F., \& Malaquias, J. V. (2014). Rede social e aposentadoria. In S. G. Murta, C. Leandro-França, \& J. Seidl (Eds.), Programas de Educação para Aposentadoria (pp. 197-209). Novo Hamburgo, RS: Sinopsys.
França, L. H. F. P., Barbosa, L. M., \& Murta, S. G. (2014). Projetos de vida, valores e ação comprometida na aposentadoria. In S. G. Murta, C. Leandro-França, \& J. Seidl (Eds.), Programas de Educação para Aposentadoria (pp. 267-287). Novo Hamburgo, RS: Sinopsys.

França, L. H. F. P., \& Sandoval, L. A. N. (2014). Relacionamentos familiares e conjugais na aposentadoria. In S. G. Murta, C. Leandro-França, \& J. Seidl (Eds.), Programas de Educação para Aposentadoria (pp. 182-196). Novo Hamburgo, RS: Sinopsys.

Günther, I. A., \& Borges, L. M. (2014). Modelos teóricos que fundamentam os Programas de Preparação para a Aposentadoria. In S. G. Murta, C. Leandro-França, \& J. Seidl (Eds.), Programas de Educação para Aposentadoria (pp. 37-53). Novo Hamburgo, RS: Sinopsys.

Kunzler, L. S. (2014). O pensar saudável na aposentadoria. In S. G. Murta, C. Leandro-França, \& J. Seidl (Eds.), Programas de Educação para Aposentadoria (pp. 165-181). Novo Hamburgo, RS: Sinopsys.

Leandro-França, C. (2014a). Aposentadoria: Crise ou liberdade? In S. G. Murta, C. Leandro-França, \& J. Seidl (Eds.), Programas de Educação para Aposentadoria (pp. 54-65). Novo Hamburgo, RS: Sinopsys.

Leandro-França, C. (2014b). Prevenção e promoção da saúde mental, políticas públicas sobre envelhecimento e educação para aposentadoria. In S. G. Murta, C. Leandro-França, \& J. Seidl (Eds.), Programas de Educação para Aposentadoria (pp. 22-36). Novo Hamburgo, RS: Sinopsys.

Murta, S. G., Borges, L. M. \& Costa, A. L., Jr. (2014). Manejo de grupos psicoeducativos. In S. G. Murta, C. Leandro-França, \& J. Seidl (Eds.), Programas de Educação para Aposentadoria (pp. 55-68). Novo Hamburgo, RS: Sinopsys.

Murta, S. G., Leandro-França, C., \& Barbosa, L. M. (2014). Pesquisa em Avaliação de Educação para a Aposentadoria In S. G. Murta, C. Leandro-França, \& J. Seidl (Eds.), Programas de Educação para Aposentadoria (pp. 288-308). Novo Hamburgo, RS: Sinopsys.

Murta, S. G., Leandro-França, C. L., \& Seidl, J. (2014). Programas de Educação para a Aposentadoria: Como planejar, implementar e avaliar. Novo Hamburgo, RS: Sinopsys. 
Neubern, M. (2014). Espiritualidade, promoção de saúde e aposentadoria. In S. G. Murta, C. Leandro-França, \& J. Seidl (Eds.), Programas de Educação para Aposentadoria (pp. 251-266). Novo Hamburgo, RS: Sinopsys.

Pimenta, M. (2014). Autonomia financeira na aposentadoria. In S. G. Murta, C. Leandro-França, \& J. Seidl (Eds.), Programas de Educação para Aposentadoria (pp. 210-226). Novo Hamburgo, RS: Sinopsys.

Seidl, J. (2014). (Re)descobrindo o lazer na aposentadoria. In S. G. Murta, C. Leandro-França, \& J. Seidl (Eds.), Programas de Educação para Aposentadoria (pp. 227-250). Novo Hamburgo, RS: Sinopsys.

Seidl, J., \& Conceição, M. I. G. (2014). Identidade, valores e novas perspectivas profissionais. In $\mathrm{S}$. G. Murta, C. Leandro-França, \& J. Seidl (Eds.), Programas de Educação para Aposentadoria (pp. 134-152). Novo Hamburgo, RS: Sinopsys.
Seidl, J., Leandro-França, C., \& Murta, S. G. (2014). Formatos de programas de educação para aposentadoria. In S. G. Murta, C. Leandro-França, \& J. Seidl (Eds.), Programas de Educação para Aposentadoria (pp. 84-113). Novo Hamburgo, RS: Sinopsys.

Zanelli, J. C., \& Antloga, C. S. X. (2014). Planejamento de Programas de Educação para aposentadoria. In S. G. Murta, C. Leandro-França, \& J. Seidl (Eds.), Programas de Educação para Aposentadoria (pp. 114-133). Novo Hamburgo, RS: Sinopsys.
Recebido:25/11/2015

$1^{a}$ revisão: $21 / 03 / 2016$

Aceite final: 25/03/2016 